\title{
Exploring the Meaning of Local Wisdom through Cloth, Candles, and Night: The Study of Batik Naga Tapa Purbalingga Motif
}

\author{
Mufi Fathuroh', Rizky Setiawan ${ }^{2}$ \\ ${ }^{1,2}$ History Education Study Program, Faculty of Social Science, Universitas Negeri Yogyakarta, Indonesia \\ mfathuroh@gmail.com
}

\begin{abstract}
The research was conducted to determine and describe Batik Tapa Naga Purbalingga both in terms of motifs, colors, and imprisoned meanings. The method used by researchers in writing this article is descriptive qualitative. While the data obtained using observation, interview, and documentation techniques. Based on the results obtained, it is known that the Naga Tapa Purbalingga batik motifs consist of dragons, buildings, dampars, elephants, birds, squirrels, tigers, deer, beetles, living trees, and plants which all form a pattern. The colors of the tapa naga purbaling ga batik are white, brown, and black. While the symbolic colors of the Purbaling ga tapa dragon are supernatural powers, power, and strength. While the function of tapa naga Purbalingga batik in ancient times is as the clothes of Purbalingga officials while on duty.
\end{abstract}

Keywords tapa purbalingga dragon batik; motive; meaning

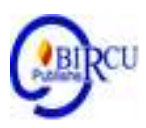

\section{Introduction}

Humans are individual creatures as well as social creatures. In relation to social creatures, humans are very likely to carry out various interactions. Good interaction with nature, the environment, and God. In relation to interaction, Sardiman (2007: 1) has explained various forms of interaction, one of which is educational interaction. Basically interaction is a process of reciprocal relations carried out by individuals and individuals, between individuals and groups, between groups and individuals, between groups and groups in social life (Aminullah, 2019). Hartanto (2020) states that society is not only a collection of a number of people, but it is also organized into groupings and institutions. Educational interactions are interactions that take place in a bond for the purpose of education and teaching. It can be said that among several forms of interaction, one of them is known as teaching-learning interaction. More specifically, it can be stated that what is called educational interaction is a teaching-learning interaction. This certainly shows the difference between humans and other creatures, where educational interactions require reason.

Education is a conscious and planned effort to create an atmosphere of learning and the learning process so that students actively develop their potential to have spiritual strength, religion, self-control, personality, intelligence, noble character, and skills needed by themselves, society, the nation and the state. (RI Law No. 14 of 2005) Talking about education, it is closely related to the progress of human civilization, where civilization is synonymous with culture. One of the cultures that need to be known is batik. Basically, batik has a meaning that is formed from complex symbols. This is because batik is made for a specific purpose, namely the goal of a good hope in order to achieve happiness, prosperity and safety in all lines of life (Gardjito, 2015: 12). Batik is one of the world's recognized 
cultural heritages. Batik is classified as an intangible cultural heritage by UNESCO. Kusrianto (2013: 304) states that the UNESCO certificate states that Batik is a Humanitarian Heritage for oral and nonbendawi cultures (Masterpieces of the Oral and Intangible Cultural Heritage of Humanity) from Indonesia.

\section{Review of Literatures}

As part of a nation that has high art, many regions have created various batik patterns. Batik as a form of expression of traditional arts of Indonesian society that is getting higher and enriches the nation's cultural treasures that can form the identity of both individuals and groups. According to Herimanto \& Warno (2012: 33) culture is the identity of the community of human life. The same is the case with Purbalingga. Purbalingga as one of the districts included in the Banyumas ex-residency certainly has a variety of local arts and cultures, such as the Tapa Naga Purbalingga batik. As one of the local cultures, Naga Tapa batik as one of the many cultural heritages passed down from the ancestors reflects the Purbalingga culture itself.

Batik Naga Tapa Purbalingga is included in the Banyumasan batik. Banyumasan batik is the name of the batik products that are produced in the former Banyumas Residency. The development of batik in the Banyumas area cannot be separated from the history of Prince Diponegoro's journey when he faced the Dutch. Where at that time, the Purbalingga area was one of the destinations for the area that was used as a place of refuge by the followers of Prince Diponegoro. After living for a long time, they must continue their life. One of them is by introducing batik. At first, batik making was only done by aristocrats. As royal descendants, noble daughters are required to have the ability to make batik. One of the noble's daughters, Mrs. Soegiarti to understand how the development of the Naga Tapa Purbalingga batik, this article will discuss the history, motifs and meanings of the Naga Tapa Purbalingga batik.

\section{Discussion}

\subsection{The Emergence of Batik Naga Tapa in the Batik Industry in Purbalingga}

Purbalingga is one of the regencies included in the Central Java Province. According to Triatmo $(2013,10)$ the Purbalingga region was designated a district in 1759 with the appointment of Ki Arsayuda (Ki Arsantaka's biological son) who had an equal position with the regent with the title Raden Tumenggung Dipayuda III. According to data from the tranquility of Sidikoro Baluwerti Kraton Surakarta, Purbalingga government facilities and infrastructure such as district houses and squares were built on July 23, 1759. After the Diponegoro War (Java Oorlod), the Governor General of the Dutch East Indies issued a decree dated 18 December 1830 to divide the Residency. Banyumas is divided into four districts, namely Banyumas, Ajibarang, Danyeuh Luhur, and Poerbolinggo (Purbalingga) districts. (Triatmo, 2013: 17).

The word Purbalingga consists of two syllables, namely ancient and phallus. Purba can be interpreted in the past or an era that lasted thousands or even millions of years ago. Meanwhile, the phallus is a stone in the shape of a pillar, a sign of the manhood of Lord Shiva, which symbolizes fertility. The name Purbalingga was taken because in this area many phallus were found that were thousands of years ago or in ancient times. According to the Central Statistics Agency of Purbalingga Regency (2014: 4) the administrative boundaries of the Purbalingga region in the north are bordered by Pemalang Regency and Pekalongan 
Regency. The eastern part is bordered by Banjarnegara district. The southern part is bordered by Kebumen Regency and Banjarnegara Regency, while the western part is bordered by Banyumas Regency. Purbalingga Regency has various cultural elements and is equipped with various arts. Each region in the Purbalingga region has its own characteristics, including batik.

The emergence of batik art in Purbalingga cannot be separated from the history of the establishment of Purbalingga Regency which is closely related to royal relatives both from Yogyakarta and Surakarta, especially in the case of the Java War. It is said that the development of batik in the Purbalingga region cannot be separated from the history of batik in Banyumas which was brought by the followers of Pangeran Diponegoro after the Java War or Java Oorlog which ended in 1830. Given that Purbalingga is included in the former Banyumas Residency, the batik produced in the former region - The residency of Banyumas is called Batik Banyumasan. As explained by Jati, et al. (2013: 30) Banyumasan batik refers to the batik produced in the ex-Banyumas residency area.

Najendra was one of Prince Diponegoro's followers who brought and introduced Batik in the Sokaraja area. Finally, batik began to develop, especially along the flow of the pelus river. Meanwhile, most of the batik workers in Sokaraja come from the ex-Residency of Banyumas, including Purbalingga, to be precise from Galuh, Limbahsari, Tlagayasa, and Kalikajar Kulon Villages (Purbalingga Regency Industry Trade and Cooperative Service, 2010: 6). The batik makers who come from the Purbalingga region work batik in the Banyumas area. After having the skills to make batik, they then carry out the batik process in their respective homes. Until the 1920s, a batik company was founded in Purbalingga under the name Batik Handel Tan Hok Dji. At that time there were two batik companies in Purbalingga, although not as big as the batik companies in Yogyakarta. It turns out that the batik skill is not only possessed by the pebatik, but also by the regent's daughters, although the activity of making batik is certainly carried out for a different purpose.

According to the results of an interview with Muhadin (31 October 2020) batik activities carried out by the regents' daughters are one of the must-have skill activities. While the batik activities carried out by batik makers are generally work done to support the economy in their lives. One of the original Purbalingga batik motifs is the tapa dragon batik made by Mrs. Soegiarti in 1940. She is one of the sixth regents, Ngabehi Dipaatmaja, the son of Raden Mas Tumenggung Dipakusuma II who later had the title Raden Adipati Dipakusuma IV. Who was appointed as regent since September 4, 1868 (Triatmo, 2013: 20). Mrs. Soegiarti was born in Purbalingga on December 28, 1897. She is the daughter of Raden Mas Taruno Saputro who is married to Reden Mas Aboesono. Raden Mas Aboesono was the second son of Purbalingga Patih who served in 1920-1938. As a noble, Mrs. Soegiarti has the title Raden Ayu.

Raden Mas Aboesono and his wife lived in the official residence of the Purbalingga post office which was in the Purbalingga Government Complex at that time. This is because, at that time, Raden Mas Aboesono served as Head of the Purbalingga Post Office. Likewise, the tapa dragon batik made by Mrs. Soegiarti was also made at the official residence. The tapa dragon batik created by Mrs Soegiarti is the result of creativity inspired by the classic tapa dragon batik motivation. This work was created during the reign of Raden Mas Aryo Soegondho, who was none other than the 9th Regent of Purbalingga from October 29, 1925 to 1942. During his reign, the dragon tapa batik was one of the long cloths used while on duty. 


\subsection{Batik Naga Tapa Purbalingga Motif}

Motif is a picture frame that is formed from various kinds of lines and points that are arranged repeatedly. The elements of the motifs found in batik are influenced by stylized elements that come from nature such as plants, animals, and humans. The same is the case with the Purbalingga tapa dragon batik. The tapa dragon batik is one of the old batik motifs made by Mrs. Soegiarti. As a result of the creativity that arises from a noble, tapa dragon batik has a quite different style. The elements of the motif in the dragon batik of Purbalingga are described as quite complicated. According to Triningsih in his final assignment, he explained that the motifs contained in the Purbalingga tapa dragon batik consisted of dragons, buildings, dampars, elephants, birds, squirrels, tigers, deer, beetles, living trees and plants.

The dragon is the main motif element found in the Naga Tapa Purbalingga batik. The dragon motif is a motif that has long been used and even existed before the HinduBuddhist era in Indonesia. Van Der Hoop in Sunarya (2009: 103). Dragons are imaginary animals. The dragon motif elements contained in the tapa dragon batik consist of ten dragons combined with various crests, crowns, fins, flowers, wings, and legs. The ten motifs of the dragon have their own description. The first dragon motif is a depiction of a dragon originating from Java. The Javanese dragon is generally described as a large snake with a crown. The second motive element is building. The building motifs found in the Purbalingga tapa dragon batik are combined with various floors or terraced bases, roofs, doors, dragons, branches, twigs, buds, flowers and leaves. The next element of the motive is the dampar. The dampar element in the Purbalingga tapa dragon batik resembles the letter V. At the base there are two curved lines that resemble inverted buds. On the inside of the motif, there are two curved lines that also resemble the buds and parallel lines running from the buds to the ends.

The next element of the motive is the elephant. Elephants are large animals that have extraordinary strength (Sunarya, 2009: 130). The elephant motif element in this tapa dragon batik is the style of an elephant animal, but combined with the wings and creeping plants found on the underside of the elephant's body. The next element is birds. The elements of the bird motif in the Purbalingga dragon tapa batik are depicted as flying and tend to be unrealistic so that the bird species is difficult to identify. The next element is Squirrel. Squirrels are known as rodents. The squirrel motif found in the Purbalingga tapa dragon batik is depicted with a squirrel sitting on a creeping plant branch. The next element is the Kijang. Deer including animals that have been immortalized in prehistoric ornaments (Sunarya, 2009: 139). The deer motif that is found in the Purbalingga tapa dragon batik is the stylus of the deer animal. Deer is depicted standing with a diagonal body direction. The next element is beetles. The element of the beetle motif in the dragon tapa Purbalingga batik motif is the style of the beetle animal, so it has a very simple element.

The next element is the Tree of Life. The elements of the motif that make up the Purbalingga tapa dragon batik are living trees equipped with supporting roots, wavy stems, flowers, buds, and leaves. Lastly, namely plants. Early use of plant motifs in Indonesia was during the time of Hindu influence. The plant motifs in question are those that are stylized from various parts of the plant such as shoots, leaves, flowers, short and long branches with curved elements or several parts of the plant that are strung together. In its application, the motif is applied to form a pattern. Pattern is a design of an image on the surface of the paper as an example of batik which will be applied on the surface of the cloth the pattern consists of several batik motifs that are arranged repeatedly so that a batik pattern will be formed. 
Tapa dragon batik Purbalingga has a pattern of application that distinguishes it from other tapa dragon batik, which is dominated by plant and animal motifs. Therefore, the Purbalingga tapa dragon batik can be classified into the cement pattern class. Whereas the Purbalingga tapa dragon batik pattern has quite a complex arrangement of motifs, so that the batik makers in the Purbalingga area are less interested in production activities. Therefore, the Purbalingga tapa dragon batik will be more difficult to find than other batik motifs.

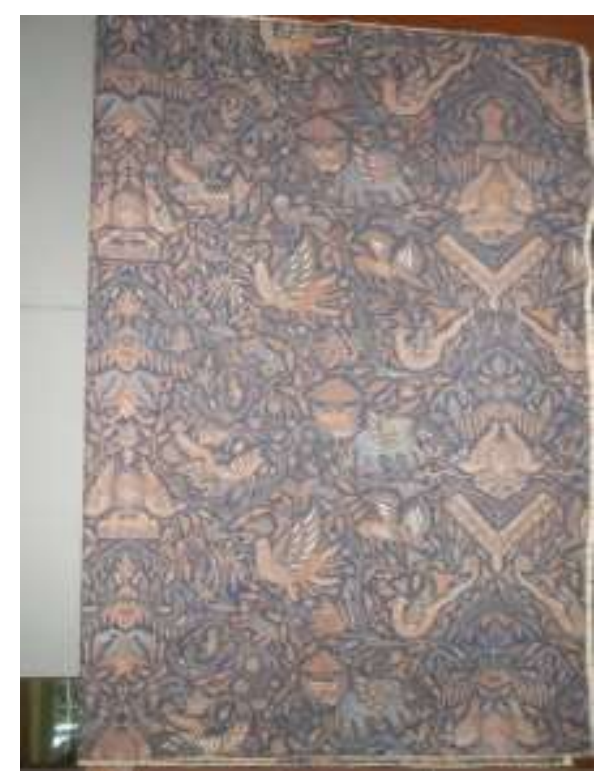

Figure 1. Batik Naga Tapa Purbalingga

Color is the effect the eye receives when an object passes light on to it. Color can add aesthetic value to a work of art. Likewise, the colors contained in the Purbalingga tapa dragon batik. The color of the batik made by Mrs. Soegiarti in 1940 consists of brown and black colors while still displaying the basic color of the fabric, namely white. Black in question is a very dark blue color that looks like black. Meanwhile, the brown color refers to the typical color of Solo batik. This makes the batik colors in Purbalingga refer to the keratn color of batik using natural dyes. Inland and palace communities consider contrasting colors to be considered harsh because they lack mriyayeni (gracefulness). Colors with dark shades are considered more elegant when worn so that they seem authoritative, especially for officials at that time. It can be concluded that the application of colors to the Purbalingga tapa dragon batik is white, brown, and black.

\subsection{The Meaning of Batik Naga Tapa Purbalingga}

A symbol is a thing or a state that is expressed by humans in interpreting their life. Symbols generally come from predecessors. The tapa dragon batik is one of the "old" batik motifs from the Purbalingga region. Batik "lawas" means old btik (ancient) which was made in 1940. In making this btik contains meanings related to Purbalingga Regency itself. The batik cloth that has been made by Mrs. Soegiarti consists of two word elements, namely dragon and tapa. The words dragon and tapa are loan words from Sanskrit. This shows that the Hindu influence that came to Java had a strong influence. Nagas have long been known to the Javanese community. Poerwadarminta (1939: 335) argues that the dragon means gedhe snake. Naga is a Sanskrit term for a snake, and in Indonesian, dragon means big ilar which is sometimes depicted with a crown. (Pinardi, 1990: 22). 
Tapa is a method used to get closer to the creator in order to achieve the desired goal. These goals can be in the form of wealth, happiness, beauty, peace and so on. Mangku (2011: 10) explains that the word tapa comes from the word "tap" which means to restrain, control or burn. What is meant is the restraint of lust or living a holy life. In simple terms, it can be concluded that the tapa dragon is a large, crowned snake that is controlling its lust with the aim of cleansing itself from the sins that have been committed so that it is able to get closer to the Creator and can achieve a prosperous life. The whole dragon motif symbolizes supernatural powers and fertility. (Kusrianto, 2013:21).

The buildings contained in the Purbalingga tapa dragon batik are combined with various floors or terraced bases, roofs, doors, dragons, branches, twigs, thas, flowers and leaves. The wake motive depicts a kind of house that symbolizes power and protection. The slap on the tapa Purbalingga dragon batik also symbolizes power, but the power in question is the power of the regents and their subordinates in regulating the Purbalingga government. The elephant found in the tapa dragon batik is a stylus from an elephant animal combined with the wings and plants creeping from under the elephant's body. There are three variations of elephant motifs in the Purbalingga tapa dragon batik. Elephants symbolize strength, greatness, strength, and justice (Sunarya, 2009: 130). The bird contained in the tapa Purbalingga dragon batik symbolizes the world above which symbolizes glory,

Squirrels are depicted sitting on branches that grow and spread. For the people of Purbalingga, the squirrel is a symbol of ingenuity. Where in exercising power, when faced with difficult situations can immediately solve them. Tiger is a symbol of strength. Deer is a symbol of agility. Beetles symbolize courage. the living tree is a symbol of protection, power, sustainability and peace. Meanwhile, plants symbolize prosperity. In addition, the colors in the Purbalingga tapa dragon batik have their own meaning. White symbolizes the east and shows the impression of innocence (innocence), purity, peace of mind, courage and the wearer's forgiveness (Kusrianto, 2013: 35). In the Purbalingg tapa dragon batik, white symbolizes sincerity. The color brown symbolizes fertility. The color brown is symbolic of the color of the fertile clay soil, it can evoke a sense of humility, simplicity and "earthiness", in addition to warmth for the wearer (Kusrianto, 2013: 35). The color black (dark blue) is a symbol of the power of luxury, sensuality, mystery and grandeur. It can be concluded that the meaning of tapa Purbalingga dragon batik is authenticity, power, and strength. While the function of tapa Purbalingga dragon batik in ancient times was used by officials while on duty. Power, strength, while the function of tapa Purbalingga dragon batik in ancient times was used by officials while on duty.

\section{Conclusion}

Batik Tapa Naga is an original batik from Purbalingga which was created by Mrs. Soegiarti. A nobleman in Purbalingga. Based on the results obtained, it is known that the Tapa Naga Purbalingga batik motifs consist of dragons, buildings, dampars, elephants, birds, squirrels, tigers, deer, beetles, living trees, and plants which all form a pattern. The colors of the tapa naga purbalingga batik are white, brown, and black. While the symbolic colors of the Purbalingga tapa dragon are supernatural powers, power, and strength. While the function of tapa naga Purbalingga batik in ancient times is as the clothes of Purbalingga officials while on duty. 


\section{References}

Aminullah, M. (2019). Human Interaction with Creators and Fellow Creatures (Study of Communication Relations of XYZ in Alamin Theory). Budapest International Research and Critics Institute-Journal (BIRCI-Journal) Vol 2 (4): 85-98.

Dinas Perindustrian Perdagangan dan Koperasi Kabupaten Purbalingga. 2010. Profil Sentra Industri Batik Purbalingga. Purbalingga: Dinas Perindustrian Perdagangan dan Koperasi.

Gardjito Murdijati. 2015. Batik Indonesia: Mahakarya Penuh Pesona.

Hartanto, D. (2020). Sociology Review of Social Phenomenon, Social Rules and Social Technology. Budapest International Research and Critics Institute-Journal (BIRCIJournal Vol 3 (2): 1175-1184.

Herimanto \& Winarno. 2012. Ilmu Sosial dan Budaya Dasar. Jakarta: Bumi Aksara.

Jati, Eling Purwoko, dkk. 2013. Analisis Sikap dan Minat Masyarakat dalam Mengembangkan Industri Kreatif di Desa Gambarsari Kecamatan Kemangkon Kabupaten Purbalingga. Journal and Proceeding, 01, IX, hlm. 30-42.

Kusrianto, Adi. 2013. Batik: Filosofi, Motif, dan Kegunaan. Yogyakarta: Andi.

Mangku, I Wayan. 2011. Materi Kuliah IPB103 Agama Hindu. Unit Mata Kuliah Dasar Umum. IPB. https://ocw.ipb.ac.id/course/view.php?id=66. Diunduh pada tanggal 12 Desember 2020.

Undang-Undang RI No. 14 Tahun 2005 dan Peraturan Pemerintah No 74 Tahun 2008. Tentang Guru dan Dosen. (Bandung: Citra Umbara, 2009).

Pemda Kabupaten Dati II Purbalingga dan LPM UGM. 1997. Sejarah Lahirnya Kabupaten Purbalingga. Purbalingga: Pemerintah Daerah Kabupaten Purbalingga.

Pinardi, Slamet. 1990. Ular (Naga) dalam Pandangan masyarakat Jawa Kuna. Koleksi karya ilmuah. Yogyakkarta: Fakultas Sastra UGM.

Poerwadarminta. 1939. Soesastra Djawa: BJ Wolters University of California.

Sunarya, Aryo. 1980. Seni Kerajinan Batik Indonesia. Yogyakarta: Balai penelitian Batik dan Kerajinan.

Triatmo. 2013. Ki Arsantara Pendiri Kabupaten Purbalingga. Purbalingga: Komunitas Pecinta Sejarah dan Budaya Purbalingga.

Unesco. 1995-2012. "Indonesian Batik". http:/www.unesco.org/culture/ich/RL/00170. Diunduh pada tanggal 5 November 2020. 